\title{
The Characteristics of Soil C, N, and P Stoichiometric Ratios as Affected by Geological Background in a Karst Graben Area, Southwest China
}

\author{
Hui Yang ${ }^{1,2}$, Peng Zhang ${ }^{1,2,3}$, Tongbin Zhu ${ }^{1,2, *}$, Qiang Li $^{1,2}$ and Jianhua Cao ${ }^{1,2}$ \\ 1 Institute of Karst Geology, CAGS, Karst Dynamics Laboratory, MNR and Guangxi, Guilin 541004, China \\ 2 International Research Centre on Karst, Under the Auspices of UNESCO, Guilin 541004, China \\ 3 School of Water Resources and Environment, China University of Geosciences (Beijing), \\ Beijing 100083, China \\ * Correspondence: zhutongbin@gmail.com; Tel.: +86-773-5837840
}

Received: 31 May 2019; Accepted: 17 July 2019; Published: 19 July 2019

\begin{abstract}
Understanding ecological stoichiometric characteristics of soil nutrient elements is crucial to guide ecological restoration and agricultural cultivation in karst rocky desertification region, but the information about the effect of the geological background on ecological stoichiometric ratios remains unknown. Soils from different landforms, including a basin, slope, and plateau, were sampled to investigate the spatial variance of the ecological stoichiometric characteristics of soil carbon (C), nitrogen $(\mathrm{N})$, and phosphorus $(\mathrm{P})$ under different rocky desertification grades (LRD: light rocky desertification; MRD: moderate rocky desertification; and SRD: severe rocky desertification) in a karst graben basin of Southwest China. Soil C:N ratio was not significantly influenced by rocky desertification grade, which was at a relatively stable level in the same landform, but soil C:P and $\mathrm{N}: \mathrm{P}$ ratios increased with increasing rocky desertification grade. This change was consistent with increased soil organic carbon (SOC) and total nitrogen (TN) concentrations in the same geomorphic location along with the intensification of rocky desertification, but soil $\mathrm{P}$ concentration remained at a relatively stable level, indicating that $\mathrm{P}$ may be the limiting macronutrient for plant growth during vegetation restoration in a karst graben area. The soil C:N ratio of slope land was larger than that of the basin and plateau, while the soil C:P ratio and N:P ratio of the slope and plateau were significantly larger than that of the basin. The correlations between $\mathrm{pH}$ and $\mathrm{C}, \mathrm{N}$, and P stoichiometry decreased significantly when Ca was used as a control variable. In sharp contrast, the correlations between Ca and $\mathrm{C}, \mathrm{N}$, and $\mathrm{P}$ stoichiometry were highly significant no matter whether $\mathrm{pH}$ was used as a control variable, suggesting the important role of $\mathrm{Ca}$ in soil $\mathrm{C}, \mathrm{N}$, and $\mathrm{P}$ stoichiometry in karst graben basins.
\end{abstract}

Keywords: stoichiometric ratios; landform; rocky desertification; karst graben basin

\section{Introduction}

Karst, which accounts for $12 \%$ of the world's total land area, is a calcium (Ca)-rich environment and a unique ecological system [1]. China has approximately 3.44 million $\mathrm{km}^{2}$ of karst areas, including buried, covered, and exposed carbonate rock areas, accounting for $15.6 \%$ of all karst areas in the world [2]. The karst ecosystem is extremely fragile, and it is ranked as the four fragile eco-environmental zones in China along with loess, desert, and cold desert [3]. Due to the fragile ecological environment, complex human-land system, and unreasonable social and economic activities, the rocky desertification widely occurs in the southwest karst region of China (Figure S1) [4]. Noticeably, the karst graben basin is a unique geomorphological form, more fragile than other karst regions in the Southwest China, due to the obvious differences in the topography and climate between basins and mountainous areas in graben basins. Furthermore, geographical environment factors (e.g., hydrology, climate, 
and soil) are complex and vegetation site conditions are poor, all of which induce serious rocky desertification [5,6]. Thus, rocky desertification control has become an important part of China's social and economic construction. In addition, vegetation after rocky desertification control is characterized by simple structure, poor stability, and weak resistance. However, the theoretical research of karst rocky desertification restoration lags far behind the practice of rocky desertification control, which seriously limits the restoration and reconstruction of rocky desertification.

It has been widely accepted that the eco-stoichiometry in terrestrial ecosystems plays an important role in biogeochemical cycle research, because it can be used to evaluate the equilibrium and coupling relationships of the main components of an ecosystem [7,8]. Among various elements, soil carbon $(\mathrm{C})$, nitrogen $(\mathrm{N})$, and phosphorus $(\mathrm{P})$ are considered to be the most important components, because the soil C:N:P stoichiometric ratio can reflect soil fertility, plant nutritional status, and the coupling changes between these elements can also affect the growth and distribution of vegetation [9]. In the past several decades, the ratios and relationships among soil C, N, and P have been extensively studied to indicate whether plant growth is limited by these nutrients [10]. The stoichiometric ratio of soil C, $\mathrm{N}$, and $\mathrm{P}$ is strongly influenced by soil type, vegetation community characteristics, climatic condition, and vegetation development stage $[11,12]$. Noticeably, soil is highly heterogeneous in time and space, especially for karst landform. With the development of rock desertification grades, except for plant loss (i.e., the reverse succession of plant communities), the changes in soil quality (e.g., physical, chemical, and biological properties) and quantity have also been significantly taken place [13,14]. In general, the positive succession of plant communities facilitates soil nutrient accumulation, while the reverse succession of plant communities exacerbates soil degradation [15], which can be further enhanced with an increasing rocky desertification grade [16-18]. However, the response of soil physical and chemical properties during the evolution of rocky desertification can show the different patterns as follows: With the increasing rocky desertification grade, the aggregation effect of bare rocks becomes more and more obvious, and the input of soil total N (TN) and soil organic carbon (SOC) is increased through atmospheric sedimentation nutrients and the karst process, while soil erosion becomes weak due to the less soil that can be lost, and subsequently soil nutrient loss is weak, which may improve soil nutrients and physical properties in a rocky desertification environment [16]. Thus, it is possible that soil quality varies with the grade of rocky desertification. Noticeably, soils that widely exist in different landforms in the karst graben basin also have different physical and chemical properties. Therefore, soil stoichiometry may be simultaneously affected by rocky desertification and topography. However, the existing reports mainly focus on the spatial distribution characteristics of soil nutrients and changing patterns during rocky desertification evolution [19]. There is no systematic study on the relationships, ratios between soil C, N, and P elements, and the affecting factors under different rocky desertification in different landforms in the karst graben basin. In addition, calcareous soil developed on carbonate rock is characterized by high $\mathrm{pH}$, magnesium $(\mathrm{Mg})$, and Ca materials in a karst region [2,20], which may lead to the obvious differences in the eco-stoichiometry of soil C, N, and P compared to other soil types. We hypothesized that the karst geological background, especially soil $\mathrm{pH}$, $\mathrm{Mg}$, and Ca concentrations, may play an important role in controlling soil C, N, and P stoichiometry.

In this study, soils from different landforms, including a basin, slope, and plateau, were sampled to investigate the spatial variance of the ecological stoichiometric characteristics of soil C, N, and P under different rocky desertification grades in the karst graben basin. In addition, other soil properties, especially $\mathrm{pH}, \mathrm{Mg}$, and $\mathrm{Ca}$ concentrations, were also determined to reveal the influencing geochemical factors for soil $\mathrm{C}, \mathrm{N}$, and $\mathrm{P}$ stoichiometric ratios.

\section{Material and Methods}

\subsection{Study Area}

The study site was located in Mengzi county, Hani-Yi Autonomous Prefecture of Honghe, Yunnan Province, China (Figure 1). It is characterized by a typical karst landscape and the topography is 
dominated by mountains and basins. Rocky desertification is usually distributed in mountainous areas with a large elevation difference and steep slopes, which results in gradient effects of water, energy, and other factors, and then forms the vertical changes in climate, biology, soil, and so on [21]. The development degree of rocky desertification in the graben basin area is restricted by geological-climatic conditions, resulting in the formation of the eco-environmental characteristics of the basin with thicker soil cover, shallow hills in the basin, slopes around the basin, and plateau areas where rocks are exposed and rocky desertification is serious [5]. According to the characteristics of the Mengzi karst graben basin, soil samples were collected along the basin, slope, and plateau (Figure 1). The annual average temperature of the basin, slope, and plateau is $19.0,15.6$, and $13.7^{\circ} \mathrm{C}$, respectively, and the annual rainfall of the basin, slope, and plateau is 663,575 , and $1027 \mathrm{~mm}$, respectively [22].
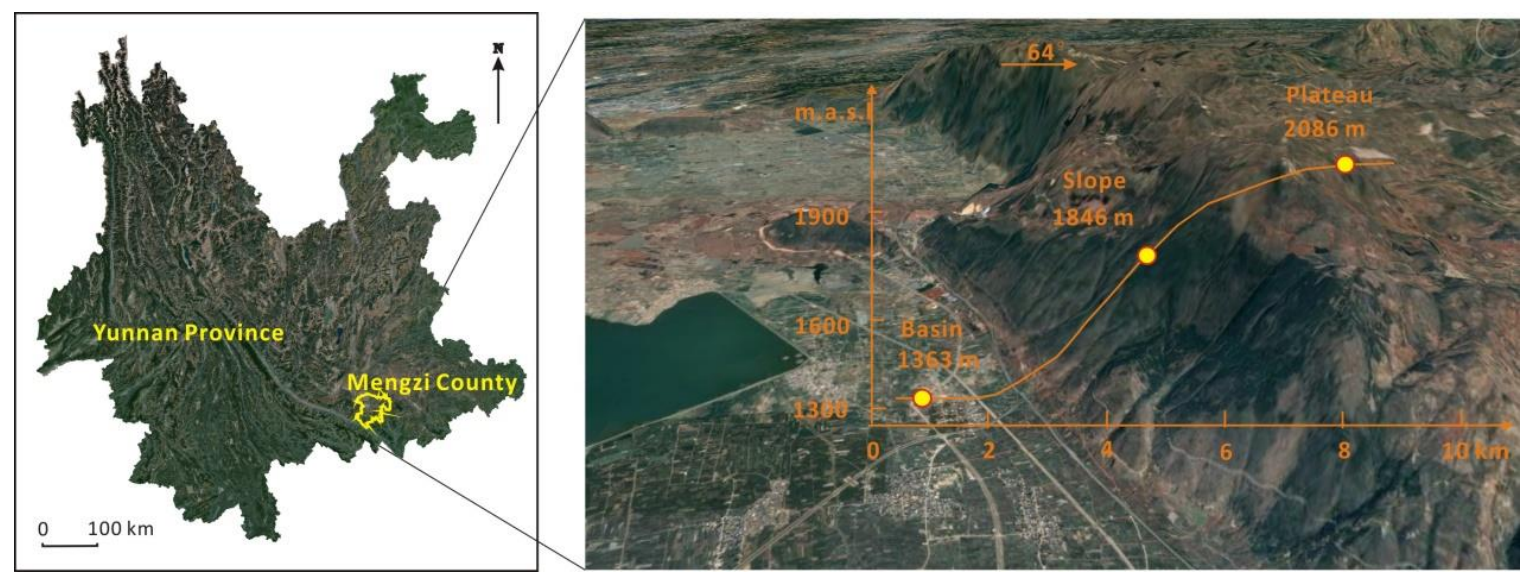

Figure 1. The location of the study area.

\subsection{Soil Sampling}

The classification of the severity of rocky desertification referred to the method of Jiang et al. (2014) [2], which has been classified into four categories according to the rock exposure rate in China: (1) No rocky desertification with a rock exposure rate $<30 \%$ of the land; (2) LRD (light rocky desertification with a rock exposure rate ranging from $30 \%$ to $50 \%$ ); (3) MRD (moderate rocky desertification with a rock exposure rate ranging from $50 \%$ to $70 \%$ ); and (4) SRD (severe rocky desertification with a rock exposure rate $>70 \%$ ).

Soil samples were collected from different geomorphic sites, including the basin, slope, and plateau. Different rocky desertification grades, including LRD, MRD, and SRD, were selected in the same landform. The details of the sampling sites, including the vegetation and rocky desertification, are shown in Table 1 and Figure S2. 
Table 1. Basic information of the study area and sampling sites.

\begin{tabular}{|c|c|c|c|}
\hline Location & $\begin{array}{l}\text { Latitude and } \\
\text { Longitude }\end{array}$ & Altitude (m) & Rocky Desertification and Vegetation \\
\hline Basin & $\begin{array}{l}103^{\circ} 23^{\prime} 47^{\prime \prime} \mathrm{E} \\
23^{\circ} 28^{\prime} 22^{\prime \prime} \mathrm{N}\end{array}$ & 1363 & $\begin{array}{l}\text { LRD: Eucalyptus forest with short planting years and single } \\
\text { community structure. The rock bareness rate was } \sim 35 \% \text {. } \\
\text { MRD: Herbs, dominated by Miscanthus. The rock bareness } \\
\text { rate was } \sim 55 \% \text {. } \\
\text { SRD: Herbs, herb of Spanishneedles (Bidens bipinnata Linn.) } \\
\text { and Canadian fleabane (Conyza canadensis (Linn.) Cronq.) } \\
\text { was dominant specie. The rock bareness rate was }>70 \% \text {. }\end{array}$ \\
\hline Slope & $\begin{array}{l}103^{\circ} 26^{\prime} 13^{\prime \prime} \mathrm{E} \\
23^{\circ} 27^{\prime} 43^{\prime \prime} \mathrm{N}\end{array}$ & 1846 & $\begin{array}{c}\text { LRD: Artificially planted cypress forests, with high canopy } \\
\text { density. The rock bareness rate was } \sim 30 \% \text {. } \\
\text { MRD: Shrub, domained by Purpus Priver (Ligustrum quihoui } \\
\text { Carr.) and Euphorbiae Pekinensis Radix (Euphorbia } \\
\text { pekinensis Rupr). The rock bareness rate was } \sim 50 \% \\
\text { SRD: Ferns are the main species. The rock bareness rate } \\
\text { was }>70 \% \text {. }\end{array}$ \\
\hline Plateau & $\begin{array}{l}103^{\circ} 27^{\prime} 09^{\prime \prime} \mathrm{E} \\
23^{\circ} 27^{\prime} 08^{\prime \prime} \mathrm{N}\end{array}$ & 2086 & $\begin{array}{l}\text { LRD: Forest, the main vegetation types are Ligustrum quihoui } \\
\text { Carr. and Chinese mugwort (Artemisia argyi H. Lév.) and } \\
\text { Vaniot. The rock bareness rate was } \sim 30 \% . \\
\text { MRD: the main vegetation types are Miscanthus. The rock } \\
\text { bareness rate was } \sim 50 \% \text {. } \\
\text { SRD: Herbs, domained by Miscanthus with a small amount } \\
\text { of Conyza canadensis (Linn.) Cronq. The rock bareness rate } \\
\text { was }>70 \% .\end{array}$ \\
\hline
\end{tabular}

LRD represents light rocky desertification; MRD represents moderate rocky desertification and SRD represents severe rocky desertification.

At least three representative plots were sampled from the LRD, MRD, and SRD area under the same landform position, resulting in 51 soil samples. The distance between sites was beyond $100 \mathrm{~m}$ under the same rocky desertification grade. At each site, 5 plots $(1 \mathrm{~m} \times 1 \mathrm{~m})$ were randomly chosen at $20 \mathrm{~m}$ intervals. Soils were obtained from the 0 to $15 \mathrm{~cm}$ layer after litter removal in each plot and all subsamples were mixed into one composite sample for each site. Fresh soil was passed through a $2 \mathrm{~mm}$ sieve, and stones and roots were removed to improve soil homogeneity and were air-dried for measurement of the soil's basic properties and nutrient element concentrations.

\subsection{Methods}

Soil $\mathrm{pH}$ was determined at a 1:2.5 (w:v) soil:water ratio by a DMP-2 mV/pH detector (Quark Ltd., Nanjing, China). SOC was measured using the $\mathrm{K}_{2} \mathrm{Cr}_{2} \mathrm{O}_{7}-\mathrm{H}_{2} \mathrm{SO}_{4}$ oxidation method; total $\mathrm{N}$ concentration was measured with the Semi-Micro Kjeldahl method; total P (TP) was determined using $\mathrm{HClO}_{4}-\mathrm{H}_{2} \mathrm{SO}_{4}$ digestion followed by a Mo-Sb colorimetric assay; and total potassium (TK) concentration was measured with the $\mathrm{HF}-\mathrm{HClO} 4$ flame photometric method [23,24]. Available $\mathrm{P}$ $(\mathrm{AvP})$ was determined by the $\mathrm{NaHCO}_{3}$-extraction method [25]. Soil $\mathrm{Ca}, \mathrm{Mg}$, copper $(\mathrm{Cu})$, iron $(\mathrm{Fe})$, manganese (Mn), and zinc ( $\mathrm{Zn})$ were extracted by $\mathrm{HNO}_{3}-\mathrm{HF}-\mathrm{HClO}_{4}$ and analyzed by Inductively Coupled Plasma-Atomic Emission Spectrometry (ICP-AES). Three replicates were performed for each soil sample.

\subsection{Data Analysis}

Soil nutrient stoichiometry was reported as a molar ratio because it could accurately reflect the amount of elements in the soil $[19,26]$. The SOC, TN, TP, and AvP concentrations $(\mathrm{g} / \mathrm{kg})$ were transformed to $\mathrm{mol} / \mathrm{kg}$. The C:N, C:P, C:AvP, N:P, and N:AvP ratios of each soil sample were then calculated as molar ratios (atomic ratios) using SOC:TN, SOC:TP, SOC:AvP, TN:TP, and TN:AvP data, respectively. 
Multiple comparisons were conducted by the Duncan method when the variance was homogeneous or the T2 Tamhane test when the variance was not homogeneous. The correlations between the stoichiometric characteristics and the environmental factors studied were analyzed by the Pearson correlation test.

\section{Results}

\subsection{General Patterns of Soil C, N, and P in the Karst Graben Basin}

In total, the average values of the C:N, C:P, and N:P ratios in the studied region were lower than those in China. However, both C:AvP and N:AvP were far higher than those in China (Table 2).

Table 2. Soil C, N, and P molar ratios in the karst graben basin.

\begin{tabular}{llllll}
\hline Landform & C:N & C:P & N:P & C:AvP & N:AvP \\
\hline Basin & $13.4 \pm 3.5 \mathrm{a}$ & $65.8 \pm 18.6 \mathrm{a}$ & $5.0 \pm 1.3 \mathrm{a}$ & $42,429 \pm 28,020 \mathrm{a}$ & $3292 \pm 2181 \mathrm{a}$ \\
Slope & $15.4 \pm 3.2 \mathrm{~b}$ & $116.0 \pm 26.2 \mathrm{~b}$ & $7.8 \pm 2.6 \mathrm{~b}$ & $81,067 \pm 36,628 \mathrm{~b}$ & $5600 \pm 3079 \mathrm{~b}$ \\
Plateau & $13.2 \pm 1.7 \mathrm{a}$ & $96.3 \pm 39.9 \mathrm{~b}$ & $7.2 \pm 2.5 \mathrm{~b}$ & $46,285 \pm 37,982 \mathrm{a}$ & $3399 \pm 2589 \mathrm{a}$ \\
Average & $13.6 \pm 2.6$ & $92.6 \pm 37.3$ & $6.8 \pm 2.5$ & $51,516 \pm 37,650$ & $3762 \pm 2682$ \\
China [27] & $14.4 \pm 0.4$ & $136 \pm 11$ & $9.3 \pm 0.7$ & $15,810 \pm 1832$ & $1114 \pm 115$ \\
\hline
\end{tabular}

SOC represents soil organic carbon; TN represents total nitrogen; TP represents total phosphorus; AvP represents available phosphorus; $\mathrm{C}: \mathrm{N}$ represents the molar ratio of SOC:TN; C:P represents the molar ratio of SOC:TP; N:P represents the molar ratio of TN:TP. C:AvP represents the molar ratio of SOC:AvP; N:AvP represents the molar ratio of TN:AvP. Identical letters indicate no significant differences in the average values among soils under different landforms at the 0.05 level.

Both SOC and TN concentrations in the basin were significantly lower than those in the slope and plateau, but no significant differences were found between the slope and plateau $(p<0.05$, Figure 2$)$. Soil TP concentration in the plateau was significantly higher than that in the slope, but the differences in soil TP concentration between the basin and slope and between the slope and plateau was not significant $(p>0.05)$.

The soil C:N ratio in the basin was significantly lower than that in the slope, while there was no significant difference between the basin and plateau $(p<0.05)$. Both the soil C:P and N:P ratios in the basin were much lower than those in the slope and plateau $(p<0.05)$, while no significant differences were found in the slope and plateau $(p>0.05$, Figure 2$)$. 

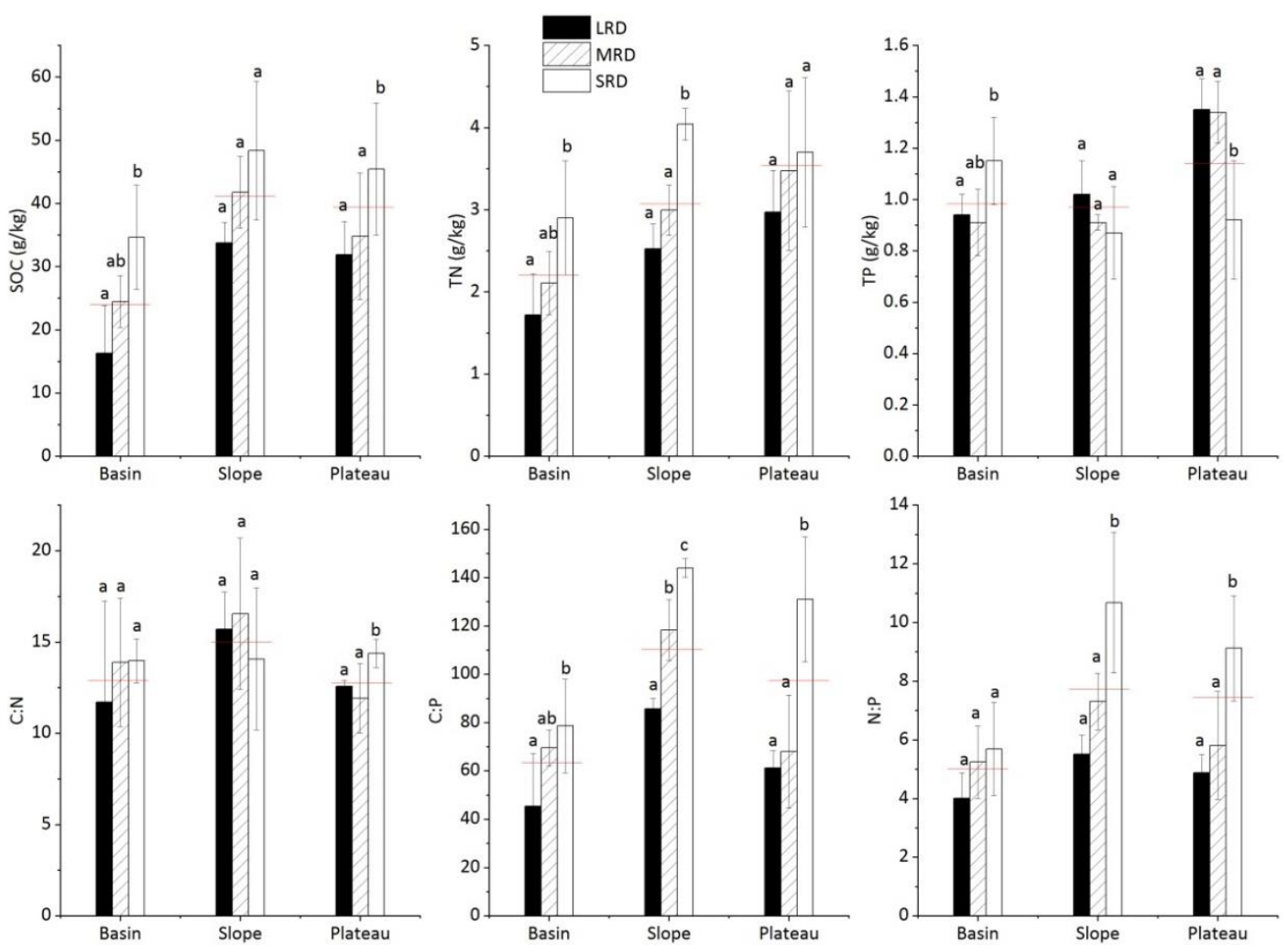

Figure 2. Soil nutrient concentrations and their stoichiometry. The red short line indicates the average value of different rocky desertification degrees in the same geomorphological location. SOC represents soil organic carbon; TN represents total nitrogen; TP represents total phosphorus; C:N represents the molar ratio of SOC:TN; C:P represents the molar ratio of SOC:TP; N:P represents the molar ratio of TN:TP. LRD represents light rocky desertification; MRD represents moderate rocky desertification and SRD represents severe rocky desertification. Identical letters indicate no significant differences in the average values among soils under different rocky desertification in the same landform at the 0.05 level.

\subsection{Soil Nutrient Concentrations and their Stoichiometry under Different Rocky Desertification}

Both SOC and TN concentrations increased with the aggravation of rocky desertification among the three landforms, while the TP concentration decreased with the aggravation of rocky desertification in the slope and plateau and there was no obvious regularity with the aggravation of rocky desertification in the basin (Figure 2).

The C:N ratios had no consistent regularity with the aggravation of rocky desertification among the three landforms, and there were no significant differences among rocky desertification in the same landform. The C:P and N:P ratios increased with the aggravation of rocky desertification among the three landforms.

\subsection{Correlations among Geochemical Variables and $C, N$, and P Stoichiometry}

The correlation between both of SOC and TN and Ca was significant under the condition of zero-order or with the $\mathrm{pH}$ value as the controlling factor. There was a simple negative correlation between the $\mathrm{Ca}$ and AvP concentration (zero-order in Figure 3). However, the Pearson correlation coefficient between the $\mathrm{Ca}$ and AvP concentration decreased significantly when $\mathrm{pH}$ was the controlling factor. Soil $\mathrm{pH}$ was positively correlated with SOC and TN (zero-order), but under the condition that $\mathrm{Ca}$ was the controlling factor, the partial correlation between both of SOC and TN and $\mathrm{pH}$ was significantly negative. Hence, Ca was the core element affecting SOC and TN concentrations. Although there was a negative partial correlation between $\mathrm{Mg}$ and SOC and TN when Ca was the controlling factor, the correlation between $\mathrm{Mg}$ and the stoichiometry of $\mathrm{C}, \mathrm{N}$, and $\mathrm{P}$ was not significant. 


\begin{tabular}{|c|c|c|c|c|c|c|c|c|c|}
\hline \multirow{4}{*}{$\begin{array}{l}\text { (Partial) } \\
\text { correlation } \\
\text { Pearson's r }\end{array}$} & \multirow[b]{2}{*}{ SOC } & \multicolumn{8}{|c|}{$\mathrm{Ca}$} \\
\hline & & $-0.46 * *$ & $-0.50 * *$ & $-0.67 * *$ & $-0.39 * *$ & 0.00 & $0.50 * *$ & $-0.29 *$ & $0.84 * *$ \\
\hline & $\mathrm{TN}$ & -0.06 & $-0.39 * *$ & $-0.52 * *$ & $-0.35^{*}$ & $0.31^{*}$ & $0.48^{* *}$ & $-0.45^{* *}$ & $0.64 * *$ \\
\hline & TP & $0.35^{*}$ & -0.08 & -0.13 & 0.02 & $0.63^{* *}$ & $0.33^{*}$ & $-0.30^{*}$ & -0.10 \\
\hline \multirow[t]{2}{*}{0.80} & AvP & 0.21 & -0.15 & -0.16 & -0.20 & 0.27 & 0.11 & -0.22 & $-0.33^{*}$ \\
\hline & & TK & $\mathrm{Mg}$ & $\mathrm{Cu}$ & $\mathrm{Fe}$ & $\mathrm{Mn}$ & $\mathrm{Zn}$ & $\mathrm{pH}$ & zero-order \\
\hline \multicolumn{2}{|l|}{0.40} & \multicolumn{8}{|c|}{$\mathrm{pH}$} \\
\hline \multicolumn{10}{|c|}{$-0.40 * *$} \\
\hline-0.40 & TN & -0.20 & -0.01 & $-0.36^{*}$ & $-0.52^{* *}$ & 0.30 & 0.22 & 0.05 & $0.72 * *$ \\
\hline \multirow[t]{3}{*}{-0.80} & TP & $0.30 *$ & 0.02 & -0.09 & 0.02 & $0.64 * *$ & $0.26^{*}$ & $-0.31^{*}$ & 0.08 \\
\hline & AvP & 0.20 & -0.13 & -0.12 & -0.07 & 0.23 & 0.07 & $-0.35^{*}$ & -0.18 \\
\hline & & TK & $\mathrm{Mg}$ & $\mathrm{Cu}$ & $\mathrm{Fe}$ & $\mathrm{Mn}$ & $\mathrm{Zn}$ & zero-order & $\mathrm{Ca}$ \\
\hline
\end{tabular}

Partial correlation controls

Figure 3. Partial correlation between $\mathrm{C}, \mathrm{N}$, and $\mathrm{P}$ and geochemical variables. $\mathrm{Ca}, \mathrm{Mg}, \mathrm{Cu}, \mathrm{Fe}, \mathrm{Mn}$ and Zn represents calcium, magnesium, copper, iron, manganese, and zinc respectively; TK represents total potassium; The color and numbers shown indicate the strength and sign of the correlation. No change in color between controlled and zero-order = no dependency; increase/decrease of color intensity = gain of /loss of correlation. Significance levels are denoted as follows: ${ }^{*}, p<0.05 ;{ }^{* *}, p<0.01$.

Undoubtedly, both $\mathrm{Ca}$ and $\mathrm{pH}$ directly influenced the $\mathrm{C}, \mathrm{N}$, and $\mathrm{P}$ stoichiometry (Figure 4 and zero-order correlations in Figure 5). Both $\mathrm{Ca}$ and $\mathrm{pH}$ were positively correlated with $\mathrm{C}: \mathrm{N}$ and C:P $(p<0.01)$. However, the relationship between $\mathrm{Ca}$ and $\mathrm{N}: \mathrm{P}$ was extremely significant and positive $(p<0.01)$, while the correlation between $\mathrm{pH}$ and N:P was not significant $(p>0.05)$. Similarly, the correlations between $\mathrm{Ca}$ and $\mathrm{C}: \mathrm{AvP}, \mathrm{Ca}$ and $\mathrm{N}: \mathrm{AvP}$, and $\mathrm{pH}$ and $\mathrm{C}: \mathrm{AvP}$ were very significant $(p<0.01)$. A significant positive correlation was found between $\mathrm{pH}$ and $\mathrm{N}$ :AvP $(p<0.05)$. 

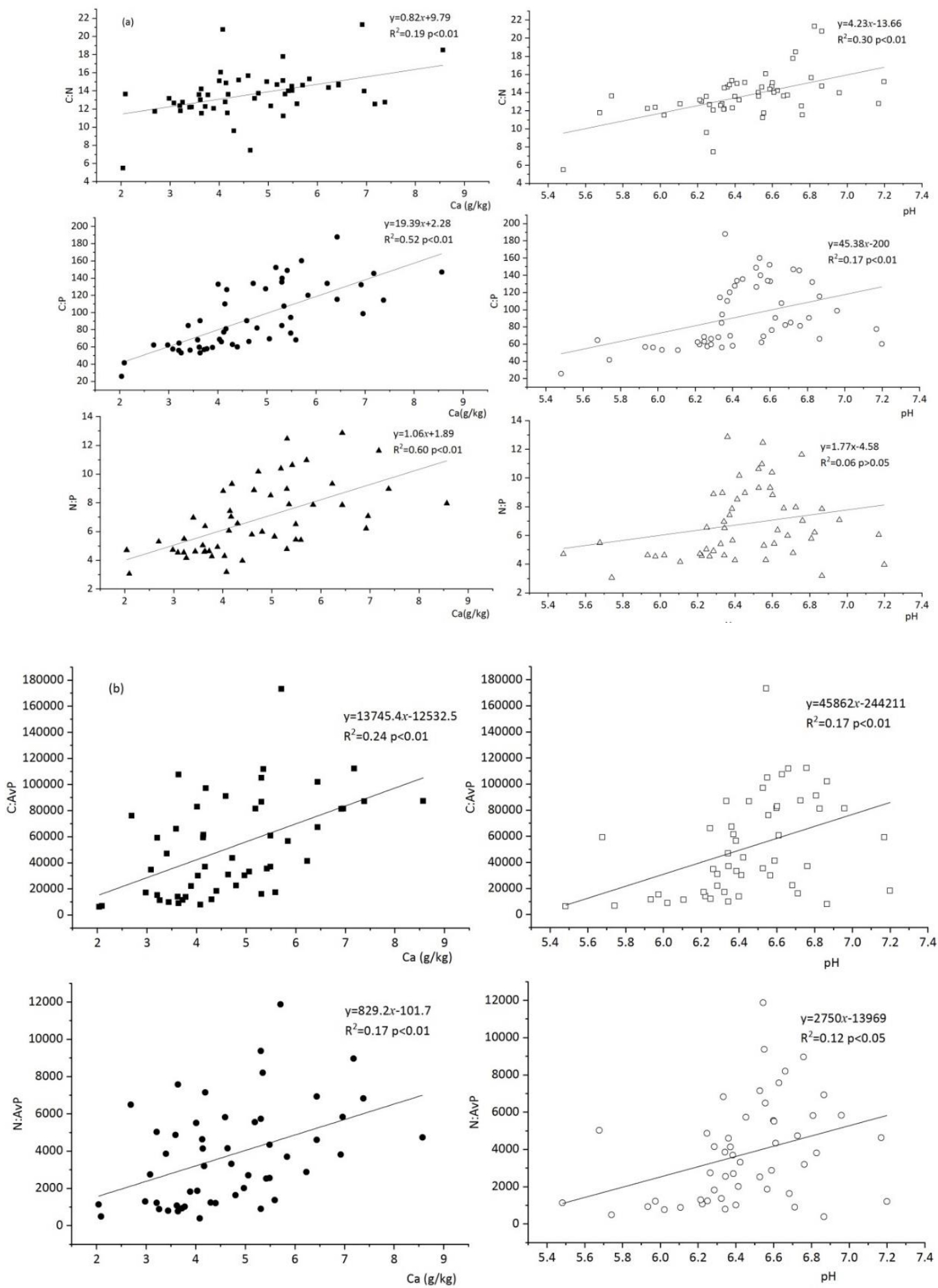

Figure 4. The relationship between $\mathrm{Ca}, \mathrm{pH}$, and $\mathrm{C}, \mathrm{N}$, and $\mathrm{P}$ stoichiometry. (a): The relationship between $\mathrm{Ca}, \mathrm{pH}$, and C:N, C:P and N:P; (b): The relationship between $\mathrm{Ca}, \mathrm{pH}$, and C:AvP, N:AvP. 


\begin{tabular}{|c|c|c|c|c|c|c|c|c|c|c|c|c|}
\hline \multirow{4}{*}{$\begin{array}{l}\text { (Partial) } \\
\text { correlation } \\
\text { Pearson's } r\end{array}$} & & \multicolumn{11}{|c|}{$\mathrm{Ca}$} \\
\hline & $\mathrm{C}: \mathrm{N}$ & 0.03 & $-0.65^{* *}$ & -0.20 & $-0.39 * *$ & 0.04 & 0.04 & 0.03 & $-0.38^{* *}$ & -0.16 & $0.42^{* *}$ & $0.44^{* *}$ \\
\hline & $C: P$ & $0.50^{* *}$ & 0.21 & $-0.70^{* *}$ & $-0.58^{* *}$ & $-0.30^{*}$ & $-0.38^{* *}$ & $-0.33^{*}$ & $-0.61^{* *}$ & 0.08 & 0.05 & $0.72^{* *}$ \\
\hline & $N: P$ & $0.41^{* *}$ & $0.55^{* *}$ & $-0.56^{* *}$ & $-0.33^{*}$ & -0.27 & $-0.34^{*}$ & $-0.34 *$ & $-0.37^{* *}$ & 0.12 & -0.11 & $0.60^{* *}$ \\
\hline \multirow[t]{2}{*}{0.80} & $C: A v P$ & -0.01 & -0.06 & $-0.64^{* *}$ & -0.27 & 0.02 & 0.10 & 0.11 & $-0.43^{* *}$ & -0.08 & 0.20 & $0.51^{* *}$ \\
\hline & $\mathrm{N}: A v P$ & -0.04 & 0.07 & $-0.61 * *$ & -0.19 & 0.04 & 0.11 & 0.08 & $-0.35^{*}$ & -0.08 & 0.16 & $0.43^{* *}$ \\
\hline \multirow[t]{2}{*}{0.40} & & SOC & $\mathrm{TN}$ & TP & TK & $\mathrm{Mg}$ & $\mathrm{Cu}$ & $\mathrm{Fe}$ & $\mathrm{Mn}$ & $\mathrm{Zn}$ & $\mathrm{pH}$ & zero-order \\
\hline & & \multicolumn{11}{|c|}{$\mathrm{pH}$} \\
\hline \multirow[t]{2}{*}{0.00} & $\mathrm{C}: \mathrm{N}$ & 0.27 & -0.24 & -0.06 & $-0.37^{* *}$ & -0.03 & -0.05 & -0.12 & $-0.34^{*}$ & -0.07 & 0.21 & $0.55^{* *}$ \\
\hline & $C: P$ & $0.77^{* *}$ & $0.61^{* *}$ & $-0.49 * *$ & $-0.52^{* *}$ & -0.06 & -0.31 & $-0.52^{* *}$ & $-0.38^{* *}$ & 0.01 & $0.65^{* *}$ & $0.41 * *$ \\
\hline \multirow[t]{2}{*}{-0.40} & $N: P$ & $0.66^{* *}$ & $0.73^{* *}$ & $-0.47 * *$ & $-0.36^{* *}$ & -0.05 & $-0.28^{*}$ & $-0.50 * *$ & -0.24 & 0.03 & $0.57^{* *}$ & 0.24 \\
\hline & C:AvP & $0.34^{*}$ & $0.29 *$ & $-0.55^{* *}$ & $-0.28^{*}$ & 0.07 & 0.05 & -0.10 & $-0.35^{*}$ & -0.06 & $0.37^{* *}$ & $0.41^{* *}$ \\
\hline \multirow[t]{2}{*}{-0.80} & $\mathrm{~N}: A v P$ & 0.26 & $0.33^{*}$ & $-0.54^{* *}$ & -0.20 & 0.08 & 0.08 & -0.08 & $-0.29 *$ & -0.07 & $0.31^{*}$ & $0.35^{*}$ \\
\hline & & $\mathrm{SOC}$ & $\mathrm{TN}$ & TP & TK & $\mathrm{Mg}$ & $\mathrm{Cu}$ & $\mathrm{Fe}$ & $\mathrm{Mn}$ & $\mathrm{Zn}$ & $\mathrm{Ca}$ & zero-order \\
\hline
\end{tabular}

Figure 5. Partial correlation between $\mathrm{C}, \mathrm{N}$, and P stoichiometry and geochemical variables. Significance levels are denoted as follows: ${ }^{*}, p<0.05 ;{ }^{* *}, p<0.01$.

\section{Discussion}

\subsection{Spatial Pattern of Eco-Stoichiometric Characteristics of C, N, and P and Analysis of Influencing Factors}

It has been widely accepted that SOC in calcareous soils in the karst region of Southwest China is significantly higher than that in other zonal soils in the same latitude $[28,29]$, which is mainly attributed to the shallow soil layer, high bareness rate, and low soil quantity in the karst area [16]. Most researchers also found that an increased SOC concentration is closely related to the geological background of Ca-rich and $\mathrm{pH}$-alkaline soils in the karst area [30-33]. Calcium in different forms plays an important role in SOC protection through a chemical bonding mechanism and chemical structure stability [34-38]. In this study, Ca was positively correlated with SOC concentration (Figure 3), indicating the important role of Ca in maintaining the SOC pool. Furthermore, SOC and TN had a significant positive correlation, suggesting the co-evolution process of the $\mathrm{C}$ and $\mathrm{N}$ cycle in calcareous soil. However, the $\mathrm{P}$ pool was not basically affected by the changes in the $\mathrm{C}$ and $\mathrm{N}$ pools, which resulted in the weak correlation between soil TP and SOC and TN. This indicates that P is mainly derived from the weathering release of soil minerals, rather than from the short-term biological cycle in this study [39]. Soil C:N, C:P, and N:P in the studied region were all lower than the average value of China, but the values of $\mathrm{C}: \mathrm{AvP}$ and $\mathrm{N}: \mathrm{AvP}$ were much higher than the average value of China (Table 1), which may be attributed to a high total P concentration but low AvP concentration in the karst soil [40].

The spatial distribution of $\mathrm{C}: \mathrm{N}$ in the studied area is relatively stable, and no significant difference was found among the three rocky desertification lands in different geomorphological locations, suggesting that the vegetation type and rocky desertification degree have little significant effect on the $\mathrm{C}: \mathrm{N}$ ratio. This was in agreement with a previous result that the C:N ratio was relatively stable and was insignificantly affected by climate, although $\mathrm{C}$ and $\mathrm{N}$ concentrations had great spatial variability [38,39]. Previous studies found that soil C:P and N:P ratios decreased with increasing disturbance, because the loss of soil C and $\mathrm{N}$ pools was faster than the P pool. However, in this study, N:P and C:P ratios increased with the aggravation of rocky desertification, more noticeably in the severe rocky desertification rock region with strong disturbance. Possibly, this could be attributed to increased SOC and TN concentrations with the aggravation of rocky desertification but the soil $\mathrm{P}$ concentration at a relatively stable level (Figure 2). Some studies found that soil physical and chemical properties do not always deteriorate with an increasing rocky desertification grade, but the degradation process initially decreases and improves after a certain stage $[16,40,41]$. This may be related to the "aggregation effect" of bare rocks in a rocky desertification environment [16], which refers to bare rock aggregated nutrients and the karst process from atmospheric subsidence into the surrounding soil. With the grade of rocky desertification, the aggregation effect of bare rock increases gradually. In the intensive rocky desertification environment, this aggregation effect becomes more obvious, coupled with the 
weakening of soil erosion, and subsequently results in the improvement of soil nutrients and physical properties, such as SOC, TN, and Ca.

\subsection{Soil Ca and pH Controls on Soil C, N, and P Stoichiometry}

Due to high Ca concentrations, calcareous soils developed by carbonate bedrock are characterized by high $\mathrm{pH}$ [42]. Soil $\mathrm{pH}$ can affect the forms and transformation of $\mathrm{C}, \mathrm{N}$, and $\mathrm{P}$ elements in the soil by changing the geochemical environment and microbial abundance, community, and activity. In addition, soil with a high Ca concentration in rock desertification areas has become the most important environmental factor affecting the local plant physiological characteristics and distribution [1]. In this study, although the correlations between $\mathrm{pH}$ and $\mathrm{C}, \mathrm{N}$, and $\mathrm{P}$ stoichiometry were highly significant (zero-order correlations in Figure 5), the Pearson correlation coefficients between $\mathrm{pH}$ and C:P, N:P, $\mathrm{C}: \mathrm{AvP}$, and N:AvP decreased significantly when Ca was used as a control variable (Figure 5). In sharp contrast, both zero-order correlations and the Pearson correlations between $\mathrm{Ca}$ and $\mathrm{C}, \mathrm{N}$, and $\mathrm{P}$ stoichiometry were highly significant, when $\mathrm{pH}$ was used as a control variable (Figure 5).

Calcium greatly impacted soil C, N, and P stoichiometry in this study. The dominant role of Ca in soil C, N, and P stoichiometry is intriguing, and Ca can supply several possible alternative explanations. Firstly, $\mathrm{Ca}$ is the necessary metabolic component of microbial growth, and fungal and bacterial heterotrophs may access and accumulate root $\mathrm{Ca}$ to form oxalates, which can be used to maintain microbial metabolism under unfavorable soil conditions [43]. Similar results were reported that Ca-rich species exhibited more rapid decomposition [44]. Secondly, Ca can combine with humus to form Ca humate, which is difficult to mineralize and decompose [28], and thereby lowers the active organic matter.

\section{Conclusions}

In this work, we analyzed the $\mathrm{C}, \mathrm{N}$, and $\mathrm{P}$ stoichiometry under different rocky desertification grades from a basin, slope, and plateau in the karst graben basin. Our results showed that the influence of the rocky desertification degree on soil C:N was not significant in the same landform, but soil $\mathrm{C}: \mathrm{P}$ and N:P increased with the increase of rocky desertification, which was attributed to increased SOC and TN concentrations in the same geomorphic location along with the intensification of rocky desertification, while the difference of $\mathrm{P}$ concentration in the same geomorphic location was not significant. This indicates that the soil quality is not deteriorating with the aggravation of rocky desertification, but has a trend of improvement. In addition, we also found that the correlations between $\mathrm{pH}$ and $\mathrm{C}, \mathrm{N}$, and $\mathrm{P}$ stoichiometry decreased significantly when Ca was used as a control variable. In sharp contrast, the correlations between $\mathrm{Ca}$ and $\mathrm{C}, \mathrm{N}$, and $\mathrm{P}$ stoichiometry were highly significant no matter whether $\mathrm{pH}$ was used as a control variable, indicating the important role of $\mathrm{Ca}$ in soil C, N, and P stoichiometry in karst graben basins. This result provides expanded guidance on the practice of ecological restoration and agricultural cultivation in karst rocky desertification regi ns. Forexample, when conducting ecological restoration of rocky desertification in karst graben basins, we should consider not only the impacts of altitude and vertical climate, but also the tolerance of species to $\mathrm{Ca}$. Selecting suitable species according to local conditions are of great significance for the promotion of ecological restoration in rocky desertification areas.

Supplementary Materials: The following are available online at http://www.mdpi.com/1999-4907/10/7/601/s1, Figure S1: Agricultural planting patterns in rocky desertification areas, Figure S2: Vegetation and rocky desertification in three sampling sites.

Author Contributions: Conceptualization, T.Z.; writing—original draft preparation, H.Y.; investigation, P.Z. and Q.L.; writing-review and editing, T.Z. and J.C.

Funding: This study was supported by the National Key Research and Development Program of China (No. 2016YFC0502501), Guangxi Natural Science Foundation (2017GXNSFAA198153) and Guangxi Scientific Research and Technology Development Project (Guikeneng 1598023-1). 
Acknowledgments: Special thanks to the anonymous referees for their valuable comments and suggestions. We also thank Junbing $\mathrm{Pu}$, Manfu $\mathrm{Hou}$, and his team for assistance with collecting soil samples and surveying plant diversity at sampling points.

Conflicts of Interest: The authors declare no conflict of interest.

\section{References}

1. Wei, X.; Deng, X.; Xiang, W.; Lei, P.; Ouyang, S.; Wen, H.; Chen, L. Calcium content and high calcium adaptation of plants in karst areas of southwestern Hunan, China. Biogeosciences 2018, 15, 2991-3002. [CrossRef]

2. Jiang, Z.; Lian, Y.; Qin, X. Rocky desertification in Southwest China: Impacts, causes, and restoration. Earth Sci. Rev. 2014, 132, 1-12. [CrossRef]

3. Yuan, D.X. Rock desertification in the subtropical Karst of South China. Z. Geomorphol. 1997, 108, 81-90.

4. Li, Q.; Pu, J.B.; Huang, N.; Du, H.M.; Qi, X.K.; Wang, L.; Yang, H. A research approach for ecological, environmental and geological differentiation of rocky desertification and its driving mechanism in karst graben basin. Adv. Earth Sci. 2017, 32, 899-907. (In Chinese)

5. Cao, J.H.; Deng, Y.; Yang, H.; Pu, J.B.; Zhu, T.B.; Lan, F.N.; Huang, F.; Liang, J.H. Rocky desertification evolution, treatment technology and demonstration in Karst faulted basins, Southwest China. Acta Ecol. Sin. 2016, 36, 7103-7108. (In Chinese)

6. Müller, M.; Oelmann, Y.; Schickhoff, U.; Böhner, J.; Scholten, T. Himalayan treeline soil and foliar C:N:P stoichiometry indicate nutrient shortage with elevation. Geoderma 2017, 291, 21-32. [CrossRef]

7. Hu, C.; Li, F.; Xie, Y.H.; Deng, Z.M.; Chen, X.S. Soil carbon, nitrogen, and phosphorus stoichiometry of three dominant plant communities distributed along a small-scale elevation gradient in the East Dongting Lake. Phys. Chem. Earth 2018, 103, 28-34. [CrossRef]

8. Mooney, H.A.; Vitousek, P.M.; Matson, P.A. Exchange of Materials Between Terrestrial Ecosystems and the Atmosphere. Science 1987, 238, 926. [CrossRef]

9. Mooshammer, M.; Hofhansl, F.; Frank, A.H.; Wanek, W.; Hämmerle, I.; Leitner, S.; Schnecker, J.; Wild, B.; Watzka, M.; Keiblinger, K.M.; et al. Decoupling of microbial carbon, nitrogen, and phosphorus cycling in response to extreme temperature events. Sci. Adv. 2017, 3, e1602781. [CrossRef]

10. Finzi, A.C.; Austin, A.T.; Cleland, E.E.; Frey, S.D.; Houlton, B.Z.; Wallenstein, M.D. Responses and feedbacks of coupled biogeochemical cycles to climate change: Examples from terrestrial ecosystems. Front. Ecol. Environ. 2011, 9, 61-67. [CrossRef]

11. Jacques Agra Bezerra da Silva, Y.; Williams Araújo do Nascimento, C.; Jacques Agra Bezerra da Silva, Y.; Miranda Biondi, C.; Cordeiro Atanázio Cruz Silva, C.M. Rare Earth Element Concentrations in Brazilian Benchmark Soils. Rev. Bras. Ciênc. Solo. 2016, 40, 1-13.

12. Wang, S.Q.; Yu, G.R. Ecological stoichiometry characteristics of ecosystem carbon, nitrogen and phosphorus elements. Acta Ecol. Sin. 2008, 28, 3937-3947. (In Chinese)

13. Li, Y.B.; Shao, J.A.; Yang, H.; Bai, X.Y. The relations between land use and karst rocky desertification in a typical karst area, China. Environ. Geol. 2009, 57, 621-627. [CrossRef]

14. Luo, G.J.; Li, Y.B.; Wang, S.J.; Cheng, A.Y.; Dan, W.L. Comparison of ecological significance of landscape diversity changes in karst mountains: A case study of 4 typical karst area in Guizhou Province. Acta Ecol. Sin. 2011, 31, 3882-3889. (In Chinese)

15. Song, T.Q.; Peng, W.X.; Du, H.; Wang, K.L.; Zeng, F.P. Occurrence, spatial-temporal dynamics and regulation strategies of karst rocky desertification in southwest China. Acta Ecol. Sin. 2014, 34, 5328-5341. (In Chinese)

16. Sheng, M.Y.; Liu, Y.; Xiong, K.N. Response of soil physical-chemical properties to rocky desertification succession in South China Karst. Acta Ecol. Sin. 2013, 33, 6303-6313. (In Chinese) [CrossRef]

17. Liu, F.; Wang, S.J.; Liu, Y.S.; He, T.B.; Luo, H.B.; Long, J. Changes of soil quality in the process of karst rocky desertification and evaluation of impact on ecological environment. Acta Ecol. Sin. 2005, 25, 639-644. (In Chinese)

18. Pang, D.; Wang, G.; Li, G.; Sun, Y.; Liu, Y.; Zhou, J. Ecological Stoichiometric Characteristics of Two Typical Plantations in the Karst Ecosystem of Southwestern China. Forests 2018, 9, 56. [CrossRef]

19. Tian, H.; Chen, G.; Zhang, C.; Melillo, J.M.; Hall, C.A.S. Pattern and variation of C:N:P ratios in China's soils: A synthesis of observational data. Biogeochemistry 2010, 98, 139-151. [CrossRef] 
20. Alfaro, M.R.; Nascimento, C.W.A.; Biondi, C.M.; Silva, Y.J.A.B.; Accioly, A.M.; Montero, A.; Ugarte, O.M.; Estevez, J. Rare-earth-element geochemistry in soils developed in different geological settings of Cuba. Catena 2018, 162, 317-324. [CrossRef]

21. Li, G.P. Progress and propects in research of mountain meteorogy in China during the past 25 years. Adv. Meteorol. Sci. Technol. 2016, 6, 115-122. (In Chinese)

22. Wang, S.N.; Pu, J.B.; Li, J.H.; Zhang, T.; Huo, W.J.; Yuan, D.X. Climatic chararacteristics under the influence of basin-mountain coupled topography and its influence on the ecological restoration of rocky desertification in a Mengzi karst graben basin, Southwest China. Carsol. Sin. 2019, 38, 50-59. (In Chinese)

23. Tyler, G.L.; Olsson, T. Conditions related to solubility of rare and minor elements in forest soils. J. Plant Nutr. Soil Sci. 2002, 165, 594-601. [CrossRef]

24. Bao, S.D. Soil Agricultural Chemistry Analysis; China Agricultural Publishing House: Beijing, China, 2000. (In Chinese)

25. Olsen, S.R. Estimation of Available Phosphorus in Soils by Extraction with Sodium Bicarbonate; United States Department of Agriculture: Washington, DC, USA, 1954.

26. Cleveland, C.; Liptzin, D. C:N:P stoichiometry in soil: Is there a "Redfield ratio" for the microbial biomass? Biogeochemistry 2007, 85, 235-252. [CrossRef]

27. Wei, F.S.; Chen, J.S.; Wu, Y.Y.; Zheng, C.J. Study on the background contents on elements of soils in China. Chin. J. Environ. Sci. 1991, 12, 12-19.

28. Zhu, T.; Zeng, S.; Qin, H.; Zhou, K.; Yang, H.; Lan, F.; Huang, F.; Cao, J.; Müller, C. Low nitrate retention capacity in calcareous soil under woodland in the karst region of southwestern China. Soil Biol. Biochem. 2016, 97, 99-101. [CrossRef]

29. Yang, H.; Zhang, L.K.; Yu, S.; Cao, J.H. Effects of different land-uses on the features of water-stable aggregates in karst and clasolite areas in Maocun, Guilin. Carsol. Sin. 2012, 31, 265-271. (In Chinese)

30. Hu, L.N.; Su, Y.R.; He, X.Y.; Li, Y.; Li, L.; Wang, Y.H.; Wu, J.S. The speciation and content of calcium in karst soils, and its effects on soil organic carbon in karst region of Southwest China. Sci. Agric. Sin. 2012, 45, 1946-1953.

31. Cao, J.H.; Yuan, D.X.; Pan, G.X. Some soil features in karst ecosystem. Adv. Earth Sci. 2003, 18, 37-44. (In Chinese)

32. Duan, Z.F.; Fu, W.L.; Zen, X.J.; Du, F.Z. Correlation between soil organic carbon and water-stable aggregate in karst area-A case study in Zhongliangshan karst valley, Chongqing. Carsol. Sin. 2009, 28, 75-79. (In Chinese)

33. Yang, H.; Zhang, L.K.; Cao, J.H.; Yu, S. Comparison of mineralization and chemical structure of the soil organic carbon under different land uses in Maocun karst area, Guilin. Carsol. Sin. 2011, 30, 410-416. (In Chinese)

34. Shen, Y.; Fu, W.L.; Lan, J.C.; Cheng, H.; Zhang, S.Q.; Wu, L.Z. Distribution characteristics of soil particulate organic carbon and mineral-associated organic carbon of different land use in karst mountain. Res. Soil Water Conserv. 2012, 19, 1-6.

35. Chen, X.B.; He, X.Y.; Hu, Y.J.; Su, Y.R. Characteristics and mechanisms of soil organic carbon accumulation and stability in typical karst ecosystems. Res. Agric. Mod. 2018, 39, 907-915. (In Chinese)

36. Yang, H.; Liang, Y.; Xu, J.M.; Cao, J.H. Research progress of the relationship between soil calcium and soil organic carbon in karst area. Guangxi Sci. 2018, 25, 505-514. (In Chinese)

37. Yang, H.; Chen, J.R.; Liang, J.H.; Cao, J.H. Preliminary study on the relationship between soil organic carbon and $\mathrm{pH}$ value and calcium species in Yaji karst region, Giulin. Geol. Rev. 2017, 63, 1117-1126. (In Chinese)

38. Yang, H.; Cao, J.H.; Sun, L.; Luan, H.N.; Hou, Y.L. Fractions and distribution of inorganic phosphorus in different land use types of karst area. J. Soil Water Conserv. 2010, 24, 135-140. (In Chinese)

39. Wen, J.; Ji, H.; Sun, N.; Tao, H.; Du, B.; Hui, D.; Liu, C. Imbalanced plant stoichiometry at contrasting geologic-derived phosphorus sites in subtropics: The role of microelements and plant functional group. Plant Soil 2018, 430, 113-125. [CrossRef]

40. Yang, H.; Zhu, T.B.; Wang, X.H.; Pu, J.B.; Li, J.H.; Zhang, T.; Cao, J.H. Soil element contents of typical small watershed in the plateau area of karst fault basin, Yunnan. Ecol. Environ. Sci. 2018, 27, 859-865. (In Chinese)

41. Sheng, M.Y.; Xiong, K.N.; Cui, G.Y.; Liu, Y. Plant diversity and soil physical-chemical properties in karst rocky desertification ecosystem of Guizhou, China. Acta Ecol. Sin. 2015, 35, 434-448. (In Chinese)

42. Bárcenas-Moreno, G.; Rousk, J.; Bååth, E. Fungal and bacterial recolonisation of acid and alkaline forest soils following artificial heat treatments. Soil Biol. Biochem. 2011, 43, 1023-1033. [CrossRef] 
43. Grabovich, M.Y.D.G.; Churikova, V.V.; Churikov, S.N.; Korovina, T.I. Mechanisms of synthesis and utilization of oxalate inclusions in the colorless sulfur bacterium Macromonas bipunctata. Mikrobiology 1995, 64, 630-636.

44. Silver, W.L.; Miya, R.K. Global patterns in root decomposition: Comparisons of climate and litter quality effects. Oecologia 2001, 129, 407-419. [CrossRef] 